\title{
Archéologie, typologie, technologie
}

\section{Olivier Buchsenschutz}

\section{OpenEdition}

\section{Journals}

Édition électronique

URL : https://journals.openedition.org/tc/859

DOI : $10.4000 /$ tc. 859

ISSN : 1952-420X

\section{Éditeur}

Éditions de l'EHESS

\section{Édition imprimée}

Date de publication : 1 septembre 1987

ISSN : 0248-6016

\section{Référence électronique}

Olivier Buchsenschutz, « Archéologie, typologie, technologie », Techniques \& Culture [En ligne], 9| 1987, mis en ligne le 23 janvier 2006, consulté le 29 septembre 2022. URL : http://journals.openedition.org/ tc/859; DOI : https://doi.org/10.4000/tc.859

Ce document a été généré automatiquement le 29 septembre 2022

Tous droits réservés 


\section{Archéologie, typologie, technologie}

Olivier Buchsenschutz 